\title{
ПІДТРИМКА ПРИЙНЯТТЯ РІШЕНЬ ПЕРСОНАЛУ ЕЛЕВАТОРА КОМБІКОРМОВОГО ЗАВОДУ
}

\author{
Tрач O.P. ${ }^{1}$, Трач M. P. ${ }^{1}$ \\ ${ }^{1}$ Одеська національна академія харчових технологій, Одеса
}

Copyright (C 2014 by author and the journal “Automation technological and business - processes". This work is licensed under the Creative Commons Attribution International License (CC BY). http://creativecommons.org/licenses/by/4.0/

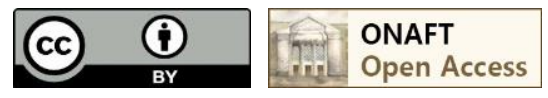

DOI: $10.15673 /$

\begin{abstract}
Анотація
Робота присвячена підвищенню ефективності управління запасами зерна на елеваторі комбікормового заводу. Виявлено основні напрямки розвитку, сформульовано склад інформаційної моделі елеватора, критерії оптимального розміщення зерна в силосах та формування оптимальної відпускної партії зерна на комбікормове виробництво. Наведено короткий опис програмної реалізації запропонованих підходів до управління запасами зерна.
\end{abstract}

\section{Abstract}

Work is devoted to increase of effective management of grain reserves on an elevator of a formula-feed plant. The main directions of development are found, the structure of information model of an elevator, criteria of optimum placement of grain in silos and formations of optimum holiday consignment of grain on formula-feed production is formulated. The short description of program realization of the offered approaches to grain stockpile management is provided.

\section{Ключові слова}

Підтримка прийняття рішень, елеватор комбікормового заводу, інформаційна модель, критерій, система підтримки прийняття рішень.

Один із шляхів підвищення економічної ефективності функціонування комбікормового виробництва $\epsilon$ забезпечення точності відтворення рецептів. Цьому питанню приділяють багато уваги при підвищенні точності дозування компонентів, при удосконаленні конструкції змішувачів, тощо. Оскільки приблизно 60\% комбікорму складає зерно, то при розрахунку рецепту комбікорму важливим $є$ не тільки необхідна кількість зерна в натуральному або відсотковому виразі, але і його якісні показники (поживна цінність, вміст перетравлюваного протеїну, вміст сирої клітковини) [1]. Тому існує значний резерв підвищення якості відтворення рецептів за рахунок урахування реальних а не середньостатистичних кількісно-якісних параметрів зерна. Отже, розрахунок і відтворення рецепту повинні грунтуватися на кількісно-якісному обліку зернової сировини комбікормового виробництва та на підтримці прийняття технологічно ефективних рішень з формування партій зерна на виробництво. Вирішенню перерахованих вище задач шляхом автоматизації підтримки прийняття рішень i присвячена ця робота.

Метою роботи є підвищення ефективності функціонування комбікормового виробництва за рахунок підвищення точності відтворення рецептури комбікормів. Досягти цієї мети пропонується у три напрямки:

- зменшення імовірності помилки оператора при управлінні рухом зерна;

- $\quad$ зменшення дисперсії якісних параметрів зерна в силосах;

- $\quad$ збільшення точності необхідних параметрів зерна при формуванні відпускної партії. 


\section{Z СТУДЕНТСЬКА НАУКА}

Для досягнення цієї мети вирішувалися наступні задачі:

- автоматизація кількісно-якісного обліку зерна в силосах елеватора;

- забезпечення підтримки прийняття рішень при розміщенні зерна на зберігання;

- забезпечення підтримки прийняття рішень при формуванні відпускної партії зерна.

Для тестування розроблюваних алгоритмів в якості об'єкта було прийнято зерновий елеватор ПАТ "Миронівський ЗВКК", який включає в себе 4 силосні корпуси $312 X 8$ силосів у кожному силкорпусі, силоси квадратного перерізу 3 Х3Х30м.

Основу кількісно-якісного обліку зерна складає чотирирівнева інформаційна модель елеватора, що включає в себе рівні елеватора, силосного корпусу, силосу та зерна, що зберігається в ньому. До параметрів зерна належать [2], [3]

- $\quad$ група параметрів, що контролюється на етапі приймання зерна, а саме: К - культура, М - маса, Н натура, В - вологість, 33 - зернова та С3 - сміттєва засміченість;

- $\quad$ група розрахункових параметрів: СВ - стан за вологістю, С33 - стан за зерновою засміченістю, СС3 стан за сміттєвою засміченістю;

- $\quad$ група параметрів, важливих для розрахунку рецептури комбікормів: а - поживна цінність зернового компоненту, b - вміст перетравлюваного протеїну, с - вміст сирої клітковини.

На рівні силосу до перерахованих вище параметрів зерна додаються:

конструктивні параметри силосу: v - об'єм, h - висота силосу;

розрахункові параметри: empty_v - вільний обєм.

На рівні силосного корпусу окрім параметрів силосів у модель додаються конструктивні особливості силосного корпусу: кількість рядів силосів, кількість силосів в ряду та загальна кількість силосів в силосному корпусі.

На рівні елеватора до моделі додаються конструктивні особливості елеватора в цілому: кількість силосних корпусів та заданий на елеваторі коефіцієнт заповнення силосів.

Підтримка прийняття рішень 3 оптимального розміщення зерна грунтується на критерії, що відображає різницю параметрів розміщуваної партії зерна (РПЗ), та партій зерна, що зберігаються (П33 ${ }_{\mathrm{i}}$ ) 3 урахуванням обмежень на змішування зерна різних культур, різних станів за вологістю та за засміченістю.

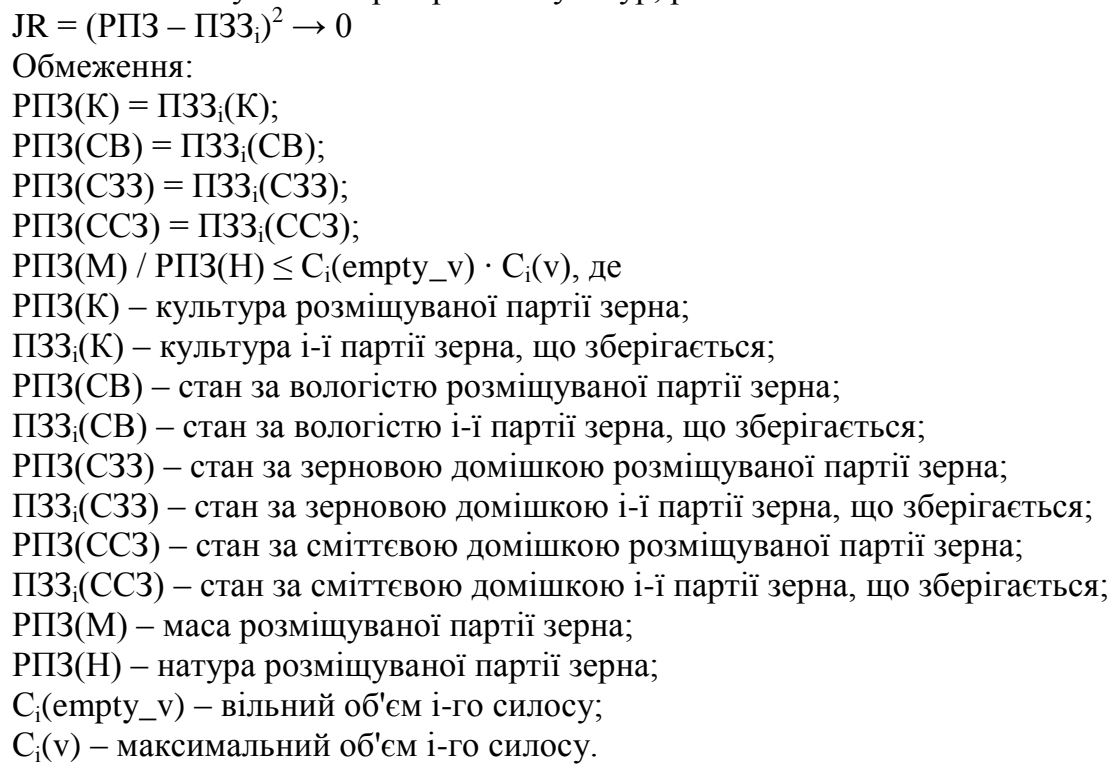

Оптимальним є варіант рішення, для якого значення критерію $є$ найменшим.

Підтримка прийняття рішень з формування оптимальних відпускних партій зерна грунтується на критерії, що відображає різницю параметрів відпускної партії зерна (ВПЗ $\left.{ }_{\mathrm{i}}\right)$, що формується та відпускних кондицій (ВК) з урахуванням обмеження на відповідність культури:

$$
\mathrm{JV}=\left(\mathrm{B \Pi} 3_{\mathrm{i}}-\mathrm{BK}\right)^{2} \rightarrow 0
$$




\section{ㄱ СТУДЕНТСЬКА НАУКА}

Обмеження:

$\mathrm{B \Pi} 3_{\mathrm{i}}(\mathrm{K})=\mathrm{BK}(\mathrm{K})$

$\left|\mathrm{BП} 3_{\mathrm{i}}(\mathrm{M})-\mathrm{BК}(\mathrm{M})\right| \rightarrow 0$, де

ВП $3_{i}(K)$ - культура i-ї сформованої відпускної партії зерна;

ВК(К) - задана культура для формування відпускної партії зерна;

ВПЗ ${ }_{i}(\mathrm{M})$ - маса i-ї сформованої відпускної партії зерна;

$\mathrm{BK}(\mathrm{K})$ - задана маса для формування відпускної партії зерна.

Оптимальним $є$ варіант рішення, для якого значення критерію $є$ найменшим.

Виконана робота дозволила сформувати основні підходи до автоматизації кількісно-якісного обліку зерна та розвитку цієї системи до рівня системи підтримки прийняття рішень. Розроблена програма реалізує функції наочного обліку руху зернових на елеваторі, та підтримки прийняття рішень персоналу елеватору 3 оптимального розміщення запасів зерна та формування оптимальних відпускних партій. Головні функції програми:

- кількісно-якісний облік параметрів збережених в силосах зернових мас;

- введення та коректування плану розміщення зерна;

- розміщення прийнятих партій зерна на зберігання;

- переміщення партій зерна, що пройшли обробку і збільшення партій зерна;

- відвантаження збережених партій зерна;

- формування оптимальних відпускних партій зерна;

- ведення журналів подій про рух зернових мас.

До додаткових функцій програми належать:

- підтримка прийняття рішень при розміщенні зерна на зберігання;

- підтримка прийняття рішень при формуванні відпускних партій зерна;

- перегляд бази даних.

Інтерфейс програми адаптований до об'єкта автоматизації, але в короткі терміни може бути перепрограмований на інші об'єкти, що включають сховища як силосного, так і складського типу.

Економічна доцільність впровадження розроблених алгоритмів та системи підтримки прийняття рішення в цілому грунтується на зменшенні імовірності помилки оператора та втрат підприємства викликаних цією помилкою. Оцінка корисності можливих варіантів рішення також дозволить підвищити економічну ефективність роботи підприємства за рахунок прийняття оператором обгрунтованих рішень. Окрім того, зменшення дисперсії параметрів партій зерна, що зберігаються, забезпечить зниження енерговитрат на переробку зерна у зв'язку з більшою стабільністю параметрів зернової сировини. Також очікується зменшення експлуатаційних витрат на зберігання у результаті контролю рівномірності навантаження на фундамент елеватора.

Науковий керівник: Світий І.М., к.т.н., доц., доцент кафедри автоматизації виробничих процесів

\section{Література}

1. http://girls4gilrs.ru/ - Сайт "Все о зерне. Технологии хранения и переработки";

2. Інструкції про ведення обліку й оформлення операцій із зерном і продуктами його переробки на хлібоприймальних та зернопереробних підприємствах, 2008 р.;

3. Машков Б.М., Хазина 3.И. Справочник по качеству зерна и продуктов его переработки. - 5-е изд., перераб. и доп. - М.: Колос, 1980. - 335 с. 